\title{
International Taxation: An Excellent Perspective for Multinational Firm Location Decisions
}

\author{
By Avi Wulandari and Feybe Brigite, STIAMI Jakarta \\ Program: Tax Management Master Degree. \\ DOI: 10.29322/IJSRP.11.01.2021.p10991 \\ http://dx.doi.org/10.29322/IJSRP.11.01.2021.p10991
}

\begin{abstract}
Multinational Corporation taxation is an area of research that encompasses academics in accounting, finance, and economics, aiming to maximize business profit over less tax paid across locations. Over the years, these researchers have endeavoured to understand the role of taxation on multinational corporation ("MNC") behaviour. International taxation arises from several activities: cross-border economic activities or investment and international trade that provides economic benefits.
\end{abstract}

\section{BACKGROUND}

A $\mathrm{n}$ increasing number of companies develop international activities in the globalization era and the progressive removal of trade barriers. To access foreign markets, firms choose between producing goods at home for exports and producing abroad. A host of tax and non-tax factors affect whether to relocate production abroad or stay within the country. The items shall affect MNCs' decision to plan where they place their locations favourable for their commercial needs.

MNCs appear to organize themselves to increase their profits invested in relatively lightly taxed jurisdictions locations. The idea to minimize the tax is by altering the location and the character of income across jurisdictions, MNCs can reduce their tax burdens. The natural extension of these lines of research, then, is determining the welfare consequences of MNCs' sensitivity to taxation.

Studies of the effect of taxation on FDI location decisions generally examine host country taxation to exclude parent country taxation. We need to check whether there will be an indication to jointly consider the impact of host and parent country taxation on multinational firm location decisions. As the first level of taxation, the host country may impose corporate income taxation on local foreign subsidiaries' income. Besides, the host country could levy a non-resident dividend withholding tax on the subsidiary's earnings when repatriated to the parent firm. Nevertheless, taxation need not stop at the host country level. The parent country

\footnotetext{
${ }^{1}$ See Philip Baker, Double Taxation Conventions and
} International Tax Law 18 (1994)

${ }^{2}$ See, e.g., OECD Model Tax Convention 2014, supra note 7, art. 7; UN Model Double Taxation Convention, supra note 4, art. 7; US Model Income Tax Treaty, supra note 9, art. 7. can further choose to levy a corporate income tax on the resident multinational's foreign-source income.

\section{ANALYSIS}

Each country has different tax regulations. Domestic tax provisions of different countries may affect two or more countries claiming each other's taxation rights on the same tax subject or tax object, for this reason, it is necessary to apply agreement which regulates that the tax regulations in force in a country do not apply to foreign residents or organizations. It refers to a special bilateral agreement agreed between the two countries that have a specific agreement. With regards to the commercial conditions for MNCs here is some analysis of the benefit of location decisions for tax planning, such as follow:

\section{a. Preventing Double Taxation through Tax Treaties}

In a typical tax treaty, the two contracting countries agree on allocating the taxing jurisdiction for different income types. Many things lead to the necessity of taxing international flows of income. One side of one country can increase state revenue from international trade and investment taxes; on the other hand, the state/government is also trying to minimize taxes that hinder trade and investment from advancing trade between countries, and the rate of investment in each country. One of the efforts to minimize this burden is to avoid international double taxation. The host country can tax foreign income without limitation, tax it up to a maximum, or not tax it at all. ${ }^{1}$ Thus, for example, income from a business activity can be taxed by the host country without restriction provided that the income is attributable to the activities of a "permanent establishment". ${ }^{2}$ However, if no such permanent establishment exists, the host will usually cede taxing jurisdiction to the residence country. Similarly, foreign residents' income from personal services rendered is also typically taxed by the host country without limitation, ${ }^{3}$ except in cases expressly excluded in the tax treaty, such as income earned by students, trainees, ${ }^{4}$ or diplomatic staff. Passive income, which usually consists of

3. See OECD Model Tax Convention 2014, supra note 7, art. 15.

4 See, e.g., OECD Model Tax Convention 2014, supra note 7, art. 20; UN Model Double Taxation Convention, supra note 4, art. 20; US Model Income Tax Treaty, supra note 9, art. 20. 
income from interest or dividend payments, is ordinarily taxed by the country in which the payment originates: the "source" country, but the tax rate is generally limited in the treaty. ${ }^{5}$

A tax treaty that grants both countries the right to tax a given type of income (with or without a limitation on the rate of taxation at source) includes a mechanism for alleviating double taxation. The UN and OECD model tax treaties, for example, recommend offering either a credit for taxes paid in the source country (the mechanism more commonly opted for by contracting countries) or an exemption for income taxed by the source country. ${ }^{6}$ When an exemption being chooses as the double- taxation alleviation mechanism in a treaty, this has usually been based on the premise that the source country will tax the exempt income. ${ }^{7}$

Some treaties set a tax-sparing mechanism for certain host countries (typically developing countries). ${ }^{8}$ Under this mechanism, the host country's incentive programs (designed to attract foreign investors) are ignoring by the residence country, and it allows its residents a credit for taxes they would have paid to the host if not for the specially targeted concessions. It serves to reduce the total level of taxation on foreign investments that fall within the treaty's scope. It thereby increases the level of crossborder investment and the benefits the host country derives from this activity. It is important to note that with this type of mechanism, the residence country gives up the tax revenues it would have collected absent the credit and allows a higher level of outbound investment into the host country than it would ordinarily prefer. On this background, OECD countries are increasingly more reluctant to include tax sparing in their treaties. ${ }^{9}$

\section{b. The Distributive Consequences of Tax Treaties}

The tax treaty agreement's function is to improve the two countries' economy and trade and remove barriers to foreign investment due to the imposition of burdensome to the two countries' taxpayers. However, here are essential similarities - and no less significant differences - between the equilibrium achieved by tax treaties and the alternative equilibria produced by the interaction between unilateral policies described above. Unilateral mechanisms can prevent double taxation just as well as a treaty mechanism and achieve the same combined taxation level. However, the equilibrium reached under treaties diverges from the

5 See, e.g., OECD Model Tax Convention 2014, supra note 7, art. 19; UN Model Double Taxation Convention, supra note 4, art. 19; US Model Income Tax Treaty, supra note 9, art. 19.

6 See, e.g., The typical withholding rates run between 0 and 15 percent. U.S. Tax Treaties 95 (Richard L. Dorenberg \& Kees Van Raad eds., 1991).

7 See, e.g., OECD Model Tax Convention 2014, supra note 7, arts. 23A, 23B; UN Model Double Taxation Convention, supra note 4, arts. $23 \mathrm{~A}, 23 \mathrm{~B}$.

${ }^{8}$ For a review see Lang \& Owens, supra note 59, at 28:

Among the BRICS, China and India have negotiated such provisions in around half their treaties, though in some credit/tax and exemption/no-tax equilibria of unilateral policies primarily in how the tax revenues distributed.

Treaties traditionally protect residence-based taxation, particularly those that constructed on the OECD model tax convention. They formulated assuming a single tax and providing residence countries with a larger revenue pie slice than unilateral mechanisms. Given the limitation on the host country's tax rates and that taxing jurisdiction over specific categories of income is given solely to the residence country, the host country collects a smaller portion of the tax revenues. As explained, treaties tend to limit the tax rate a host country can impose on passive income. Except for cases in which the relevant treaty allows tax-sparing, under a credit mechanism, a reduction in host country taxation does not translate into a larger volume of foreign investment and in fact, amounts to no more than a revenue shift from the host to the residence country. Therefore, a credit mechanism results in the residence country, collecting taxes that the host country has relinquished.

Basically, the existence of tax collection by the state on income from international trade and investment activities shows that there are benefits from international trade and investment for the two countries that work together to increase state revenues. However, the distributive divergence between the treaty outcome and unilateral outcomes occurs when a treaty limits the host country's authority to tax certain kinds of income, such as business income in the pre-permanent establishment phase and certain types of income from personal services. In such cases, the treaty prevented the host country from imposing any taxes on these income types. The outcome is that the residence country collects all of the tax revenues.

Consequently, although treaties and unilateral mechanisms achieve approximately the same reduction in double taxation, they allocate tax revenues between the host and residence countries differently. In constraining the host's power to tax, tax treaties essentially give residence countries a larger piece of the tax revenue pie. To be sure, as recent scholarship has shown, host countries and their treaty negotiations with residence countries are not all cut of the same cloth, and the specifics of the treaties they sign vary. ${ }^{10}$ However, when compared to the non-treaty equilibria, these treaties all constitute an inferior arrangement for source

cases the provisions have expired. The middle and high income developing countries reviewed (apart from Colombia) have also been active in including tax sparing in their treaties. Among the resource rich countries Nigeria and Zambia have included such provisions in most of their treaties. Among the sample of LDCs Bangladesh, Kenya and Mozambique have negotiated tax sparing provisions in many of their treaties.

\footnotetext{
${ }^{9}$ See id. at $29-30$

${ }^{10}$ Martin Hearson, Measuring Tax Treaty Negotiation Outcomes: The ActionAid Tax Treaties Dataset 36 (ICTD Working Paper No. 47, Feb. 2016)
} 
countries in terms of tax revenues, and none offer the advantages of increased foreign investment.

\section{c. Reality Check: Do Treaties Increase Foreign Direct Investment?}

Since tax treaties tend to allocate tax revenues more generously to residence countries than their unilateral alternatives, it is clear why these countries would favour such agreements. Limiting the level of taxation a host country can impose allows the residence country to collect more tax revenues without changing the overall level of taxation on outbound investments. This understanding, alongside the collateral benefits of treaties in terms of certainty, administrative convenience, and enforcement, quite possibly motivates residence countries to enter into tax treaties.

Nevertheless, why should host countries have an interest in signing tax treaties? Treaties reduce their tax revenues while doing nothing to lower the tax barriers for foreign investment from residence countries since the total taxation level remains the same. Can this arrangement be in any way beneficial to a host country? The answer could depend on the particular type of treaty in question. While asymmetrical treaty might be a deal worth making for any country, an asymmetrical agreement might not be advantageous to predominantly host countries, which is the case with developing countries. This latter type of country tends to lose revenues with a tax treaty, without providing increased tax incentives for cross-border investment.

How Profit Shifting Works: Companies have many different ways to shift profits offshore. Simple methods include mispricing international trade transactions that occur within the multinational company, such that purchases from low-tax affiliates are overpriced, and purchases from high-tax affiliates are under the price. Such techniques make the low-tax affiliates appear disproportionately profitable. Although companies are supposed to price such transactions as if they were occurring at arm's length with unaffiliated companies, there is often substantial leeway regarding transfer prices to minimize global tax burdens. Companies may also structure their finance such that interest deductions are more likely for those affiliates in high-tax countries, reducing taxable income accordingly. Companies may also use cost-sharing arrangements or other methods to transfer intellectual property to low-tax foreign jurisdictions, where the resulting profits can then reported. Finally, companies have been adept at creating opaque chains of ownership and hybrid organizational structures to generate so-called stateless profit that goes untaxed in any jurisdiction ${ }^{11}$

If companies can offshore profits without real offshoring investment, then the tax system might not distort the location of production activity. Companies can simply put jobs and investments in their most productive locations, and shift the resulting profit to the most lightly taxed jurisdiction. However, if profit shifting is limited or profit shifting is facilitated by having a real economic presence in tax havens, tax rate differences across countries will encourage profit shifting and jobs and investments to taxed locations more lightly. While real economic activities are less responsive to tax rate differences across countries than the tax base itself (due to profit shifting), real economic activities still respond to tax rate differences, and the perceived mobility of real economic activity has been a significant impetus toward competitive tax rate reductions over previous decades.

Concerns about Offshoring generate the same trade-offs that discuss above. To keep the business location as tax competitive as possible, made lighter tax rates are desirable; however, lowering corporate tax rates (at current levels) lowers corporate tax revenues, unless rate reductions offset with other changes in tax rules that broaden the tax base.

\section{Here are some effects on Offshoring:}

If companies can offshore profits without real offshoring investment, then the tax system might not distort the location of production activity. Companies can simply put jobs and investments in their most productive locations, and shift the resulting profit to the most lightly taxed jurisdiction. However, if profit shifting is limited or profit shifting is facilitated by having a real economic presence in tax havens, tax rate differences across countries will encourage profit shifting and jobs and investments to taxed locations more lightly.

While real economic activities are less responsive to tax rate differences across countries than the tax base itself (due to profit shifting), real economic activities still respond to tax rate differences, and the perceived mobility of real economic activity has been a significant impetus toward competitive tax rate reductions over previous decades.

Concerns about the same trade-offs that were discussed above, such as to keep the country location as tax competitive as possible, lighter tax rates are desirable; however, lowering corporate tax rates (at current levels) lowers corporate tax revenues unless rate reductions are offset with other changes in tax rules that broaden the tax base.

\section{CONCLUSIONS}

After Firms that operate in several jurisdictions are subject to several tax rates and several tax regulations. The interplay between rules and rates leads to a multitude of potential tax obligations facing these firms. As multinational corporations income is adapting to overlapping tax claims, MNCs have developed various tax avoidance avenues, complicating tax authorities' tax collection. Such tax-avoiding behaviour may reduce tax revenue and distort international financial flows, the international allocation of investment, and MNCs' expansion plan throughout the world. An important policy question is to what extent these tax avoidance incentives affect MNCs' behaviour and reduce tax revenue.

Most governments also have been known to use the tax system to attract foreign investment and acquire leverage over MNCs' that they believe are unfairly escaping taxation in their jurisdiction. In some countries, some reform tax policy is also published and applied in emerging countries, an example in Indonesia in 2020 that helps attract foreign investors to invest in the country. Competition attracting foreign investor well known around the Asia Pacific regions. Hence, there are often competing

\footnotetext{
${ }^{11}$ Kimberly Clausing, Reed College, Taxing Multinational Companies in the $21^{\text {st }}$ century.
} 
incentives that lead to conflicting objectives between an MNC's home country and the countries where they do business. Further, many countries are broadly defined to be tax-havens. A tax haven can be any country that reduces its statutory tax rates to attract foreign investment, in which most of the big foreign corporations reside. Not only does a relatively low tax rate potentially attract investment but it also likely increases the incentives for a firm operating in a nearby high-tax jurisdiction to shift its profits out of the high-tax jurisdiction into its low-tax neighbour. Many legislators argue that havens are bad for the US. Nevertheless, if a US MNC reduces its foreign tax burden, then, as described below, it is effectively increasing its domestic tax burden. Furthermore, the US and the UK are known to be particularly astute in pursuing taxpayers who appear to be aggressively undertaking income shifting to low-tax jurisdictions.

This paper concludes that most Multinational Company will refer to the most profitable headquarters that can provide the best solutions in terms of locations that provide no double tax arrangement, boosting profit and eliminating tax expense. In most cases, Multinational clients tend to absorb any double taxation expense in their consolidated financial statement if there is no way out or solutions to avoid any double taxation exposure.

Thus it is always interesting to discuss in all aspects of double-income tax-related of Multi-National Company and how they operate their operations globally in the long run.

\section{AUTHORS}

First Author - Avi Wulandari, Program: Tax Management Master Degree.

Second Author - Feybe Brigite, Program: Tax Management Master Degree.

Third Author - STIAMI Jakarta, Program: Tax Management Master Degree. 